although it was in Great Britain that the industrial revolution had its first beginnings and industrial development was most rapid". In his next report he introduced the same theme, "Industries for the most part are not yet fully alive to the importance of the human factor in production and to the still greater part this is destined to play in the future". It is partly due to the early work of Sir Duncan that these words are less true now.

In his early organization each investigator was responsible for a particular industry, and the investigators concerned themselves principally with hours of labour and the general environmental conditions likely to cause undue fatigue. As time went on investigators developed individual interests and worked along more specialized lines. As an organizer, Sir Duncan interfered as little as possible with his staff, although he was always willing to help where help was needed, either in making arrangements with a particular firm, or advising on the form of a report ; and no small part of the work of the Industrial Health Research Board has been made possible by his unobtrusive but valuable help. By 1930 there had been published fifty-six reports dealing with hours of labour, lighting, heating and ventilation, vocational guidance, boredom, accidents, time and motion study.

There was an entire absence of 'red tape' in his dealings with his staff, and all, however junior, could have access to him. He had a remarkable poise of personality which made him at home with people of all ages and social class. He could without conscious effort talk equally easily to a factory worker or a duchess, to an industrial magnate or a humble apprentice, and to go round a factory with him was invariably a valuable experience. He was unusually scrupulous in giving credit to researchers and in acknowledging their work. He had many interests outside his work and was an excellent amateur musician.

Sir Duncan's official retirement was in name only, for he carried on numerous activities after the outbreak of war, serving as chairman of the National Industrial Electric Lighting Service and of the Home Office Committee on Factory Lighting, a subject that had always been of great interest to him. He will, however, always be affectionately remembered by his colleagues for his humanity.

\section{Prof. Paul Bertrand}

Son of the distinguished palæobotanist Charles Eugène Bertrand (1851-1917), Paul Bertrand, the report of whose death has recently reached Great Britain, followed up his father's work on fossil plants, and became a leader in palæobotanical research. He was professor of palæobotany in Lille until 1938, when he was appointed to the chair of comparative anatomy for the study of fossil plants at Paris. He died in Paris after a short illness aggravated by privation and anxiety on February 24, 1944.

Most of Bertrand's published work falls within the period 1910-39. His most important contributions to the literature of his subject fall into two groups. His work on the Carboniferous floras of the French coal-measures has proved indispensable to students of Carboniferous stratigraphy in Europe and America. His recognition and demonstration of stages or zones in the succession of vegetation in the Carboniferous which could be recognized and defined by their floristic composition will remain, just as the corre- sponding work by Kidston in Britain, a classic example of the application of palæobotanical research to geology. Their work has led up to more recent work by Dr. Dix in South Wales and by many workers in North America. As an accompaniment to this work he produced monographs of outstanding quality on the Pteridosperm genera Alethopteris, Mariopteris and Neuropteris.

The essence of all this research is contained in Bertrand's contributions to the Comptes rendus of the Congresses on Carboniferous Stratigraphy held in Heorlen in Holland in 1927 and 1935. On the botanical side, his work on Algæ (Botryococcaceæ) found as constituents of certain coals, and on the anatomy of Devonian and Carboniferous ferns, is of outstanding quality and importance. Here he ranks with Williamson, Scott, Kidston and Lang as an outstanding contributor to our knowledge of the anatomy of Devonian and Carboniferous plants.

Bertrand kept in touch with a wide circle of friends interested in palæobotanical work, and, with Mme. Bertrand, who survives him, regularly attended international meetings. Those who were privileged to know him will remember his quiet unassuming character, and his unfailing sympathy and interest in his friends' difficulties and problems. 'To know the Bertrands was to know what is best and most charming in the French character. His death causes an irreparable loss to many-especially to his younger colleagues, to whom he was unfailingly helpful.

\section{JOHN WALTON.}

\section{Dr. Max Bergmann}

Dr. Max BergmanN, the distinguished chemist, died in New York on November 7, 1944, at the age of fifty-eight. Dr. Bergmann, who was born in Fuerth, Bavaria, studied chemistry in Munich and received his $\mathrm{Ph} . \mathrm{D}$. degree in the University of Berlin in 1911. He then entered the laboratory of Emil Fischer, where he worked until the latter's death in 1919. In 1921 Bergmann became director of the Kaiser Wilhelm Institute for Leather Research in Dresden, a position which he held until 1934. Shortly after Hitler came to power, Bergmann, being a Jew, resigned his post and accepted the position of an associate nember of the Rockefeller Institute for Medical Research in New York. He was appointed a member of the Institute in 1937 and occupied this position at the time of his death.

Bergmann's work up to the time when he left Germany followed fairly closely both in subjectmatter and in his way of approach that of his great master, Emil Fischer. It was concerned, almost exclusively, with the organic chemistry of aminoacids and carbohydrates. Fischer had discovered a new class of sugar derivatives, the glycals, but Bergmann proved that the structure assigned to them was not correct. He showed that these compounds were not aldehydes as Fischer had assumed, and also demonstrated the presence and position of a double bond and established the size of the ring. Another field of sugar chemistry in which Bergmann made notable contributions was that of chitin and glucosamine. His isolation of the disaccharide, chitobiose, was contemporary with that of Zechmeister.

The main interest of Bergmann was, however, in amino-acids. He extended greatly our knowledge of the azlactones, the highly reactive unsaturated anhydrides formed from amino-acids; his last paper, which appeared after his death, was devoted to this 
subject. He was interested in most aspects of the organic chemistry of amino-acids, and it is difficult to single out particular contributions. His work was distinguished by a real elegance in conception and great skill in execution. Thus, his model experiments on the formation of creatine from arginine anticipated by many years more recent work on the occurrence of this reaction in the living animal. Bergmann's papers covered the problems of acyl migration, racemization, reactions of $\beta$-hydroxy- $\alpha$-amino-acids, unsaturated peptides, and many others. His crowning achievement during that period was, however, his novel and important general method of peptide synthesis. The classical methods of Fischer permitted only the preparation of peptides made from simple amino-acids. Bergmann's new method made use of $\mathrm{N}$-carbobenzoxy derivatives of amino-acids; the acyl substituent protected the amino-group during the condensation and could afterwards be easily removed by catalytic reduction. This new method made possible the synthesis of almost any desired peptide.

Bergmann's work during his second, American, period was turning away from pure classical, organic chemistry, and more concerned with the structure and biochemistry of proteins. He showed for the first time that the pure crystalline, peptic and tryptic enzymes which had been prepared by Northrop and his school would act not only on proteins, as had been thought hitherto, but also on certain peptides. The work dealing with the substrate specificity of these enzymes was of much importance for our knowledge of enzymes and helped greatly towards a better understanding of the structure of proteins. Berg. mann's work also extended to the proteinases of plants and those of animal tissues. Another field in which Bergmann made very important contributions was that of the analysis and isolation of amino-acids present in proteins; he discovered many specific precipitating agents for amino-acids and devised new and interesting methods of analysis. Together with Niemann he formulated the so-called 'frequency-law', which assumed that the different amino-acids in a protein molecule are present in certain restricted proportions. Although the exact quantitative relationships assumed may have to be modified, the emphasis on stoichiometric regularities has greatly stimulated analytical work and focused attention on the regularity of the internal architecture of protein molecules.

The loss of Dr. Bergmann will be felt by organic chemists and biochemists all over the world; he leaves a widow and two children. A. NEUBERGER.

\section{NEWS and VIEWS}

Glass Technology at Sheffield :

Prof. W. E. S. Turner, O.B.E., F.R.S.

THE announcement that Prof. W. E. S. Turner is to retire from the chair of glass technology in the University of Sheffield, which he has held since 1920, comes as rather a shock. Prof. Turner's name has become so closely associated with the application of scientific principles to glass manufacture that it is hard to visualize the industry without this association. In 1914, Prof. Turner was responsible for the setting up of a Scientific Advisory Committee of the University of Sheffield to deal with technical problems arising in the local industries and, following on this work, was led to prepare a report on conditions in the glass industry. This report also made recommendations to the University Council, with the result that a Department of Glass Technology was set up in June 1915. This work was organized by Dr. Turner, as he then was, and in 1920 the Council converted this Department to a chair of the University. From that date to the present, Prof. Turner has made and established a name in connexion with the glass industry which will stand for all time.

Prof. Turner founded the Society of Glass Tech. nology in 1916, and has been editor of the Society's journal throughout its existence. He has been president of the Society on two occasions, 1922-24 and 1937-38, and has acted as secretary for three long periods. Prof. Turner has also been instrumental in initiating international meetings between glass technologists in America, France, Belgium, Germany and Denmark, founding the International Congress on Glass, the first meeting of which was held in Milan in 1933. He was also responsible for instituting the Glass Convention, which brought together industrialists, administrators, commercial representatives and glass technologists. The teaching work of the Department under his guidance has been of such importance that many of his former students now occupy important positions throughout the industry. His researches cover the whole range of glass technology and scientific research into glass and related problems. There can be few instances where one man has become so closely identified with an industry and where, in the lifetime of one man, and to a great extent due to his efforts, that industry has developed from one depending almost entirely on craftsmanship to the position where scientific control and mechanized processes have been so fully established.

\section{Dr. Harry Moore}

Dr. HARRY Moore, who has been appointed by the Council of the University of Sheffield to succeed Prof. Turner on his retirement, will bring with him to the task the benefit of a broad academic training and research experience, coupled with exceptionally wide and specialized technological knowledge. After a distinguished student career at the Royal College of Science during 1904-7, followed by a year as a demonstrator in the Physics Department of the College, he was, in 1908, appointed lecturer in physics at King's College, London, a post which he held until 1915. While there he published in the Philosophical Magazine, the Proceedings of the Royal Society and the Proceedings of the Physical Society papers on the influence of X-rays on various substances. Another group of papers on X-rays appeared between 1924 and 1928 in the British Journal of Radiology. During 1915-19 he was busy in connexion with Ministry of Munitions training schemes, finally being transferred to the Ministry of Labour Training Department as chief technical officer for south-west England. In 1919 he was appointed assistant director of research of the British Scientific Instrument Research Association under Sir Herbert Jackson, and when Sir Herbert retired in 1933, Dr. Moore succeeded him. In 1937, Messrs. Pilkington Brothers decided to build and equip extensive research laboratories and invited 